\title{
Pyroclastic material from the Upper Triassic deposits of Sassenfjorden, Spitsbergen
}

\author{
ROMAN CHLEBOWSKI AND ANDRZEJ WIERZBOWSKI
}

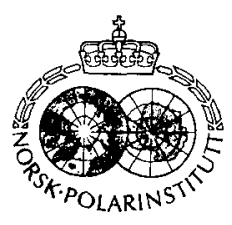

Chlebowski, R. \& Wierzbowski, A. 1983: Pyroclastic material from the Upper Triassic deposits of Sassenfjorden, Spitsbergen. Polar Research 1 n.s., 75-81. Oslo.

Pyroclastic material of a rhyolite type is present in some thin layers in the upper part of the De Geerdalen Formation in the Sassenfjorden area. This is the first evidence of late Triassic (Norian-Rhaetian) volcanic activity in Svalbard.

Roman Chlebowski, Warsaw University, Institute of Geochemistry, Mineralogy and Petrography, Al. Zwirki i Wigury 93, 02-089 Warszawa, Poland; Andrzej Wierbowski, Warsaw University, Institute of Geology, Al. Zwirki i Wigury 93, 01-089 Warszawa, Poland. April 1981 (revised October 1982).

\section{Introduction}

Recent studies resulting from Norwegian expeditions and the Polish Spitsbergen Expedition in 1979 have produced new stratigraphical, palaeontological and petrographical information on the uppermost Triassic sequence in the southern Sassenfjorden area (Bjærke \& Dypvik 1977; Wierzbowski et al. 1981). For the first time a microscopic study of thin sections from the sequence has led to the discovery of Late Triassic material of a volcanic origin. Up till now, no unequivocal evidence has existed of Late Triassic volcanic activity on Spitsbergen and the neighbouring areas.

The material has been collected in the Sassenfjorden area by Andrzej Wierbowski, who is lso responsible for the geological setting pre;ented in this paper. Responsibility for the petrographical part of the investigation lies with Roman Chlebowski.

\section{Seological setting}

The section studied is in the southern Sassenjorden area, on the western bank of an unnamed tream flowing from the northern slopes of Nimanfjellet, and is situated about $900 \mathrm{~m}$ from ts mouth (Figs. $1 \& 2$ ). Its approximate coordilates are: $70^{\circ} 20^{\prime} 40^{\prime \prime}$ and $15^{\circ} 57^{\prime} 10^{\prime \prime}$.

The sequence is about $30 \mathrm{~m}$ thick, and for lescriptive purposes it can be subdivided into six ınits, A-F, as characterized below (Fig. 1a; for nore detailed information compare also Wierowski et al. (1981); see Bjærke \& Dypvik (1977) vhere, however, somewhat different letter designations were given). The oldest rocks are grey shales with subordinate intercalations of well sorted, quartz-mica sandstones of unit $A$, the thickness of which exceeds $10 \mathrm{~m}$. The overlying, very fine-grained, strongly bioturbated sandstone layer, $0.3 \mathrm{~m}$ thick, represents unit B. It is followed by a $4.3 \mathrm{~m}$ thick deposit of unit C. At the base of this unit there appears a thin $(0.1 \mathrm{~m})$ layer of grey shales which is covered with a thin $(0.2 \mathrm{~m})$ layer of brown weathered arenaceous ironstone containing a rich bivalve fauna. This in turn is overlain by a $4 \mathrm{~m}$ thick layer of grey shales and silty shales with subordinate, thin intercalations of mudstones and fine-grained sandstones. Upwards, a very thin horizon of conglomerate occurs, here denoted as unit $\mathrm{D}$. The conglomerate is composed mainly of small rounded phosphatic nodules and dolomite-siderite pebbles up to $0.5 \mathrm{~cm}$ in diameter. The overlying unit $E$ consists of horizontally-bedded sandstones; it is about $2 \mathrm{~m}$ thick. The sandstones are well sorted, composed of quartz and rich in glauconite. In the uppermost part of unit $E$ a thin shaly layer occurs covering the erosion surface, which is penetrated by numerous vertical burrows and impregnated with a ferruginous crust. Unit $F$ is composed of dark grey shales and silty shales with frequent concretions and some intercalations of clay iron-stones occurring mostly in the lower and middle part of the unit. The iron-stones contain a relatively rich bivalve fauna (mostly of genus Halobia).

The described sequence is generally attributed to the De Geerdalen Formation. The upper part of the sequence, from unit $D$ upwards, is recognized as the Wilhelmøya Member (Bjærke 


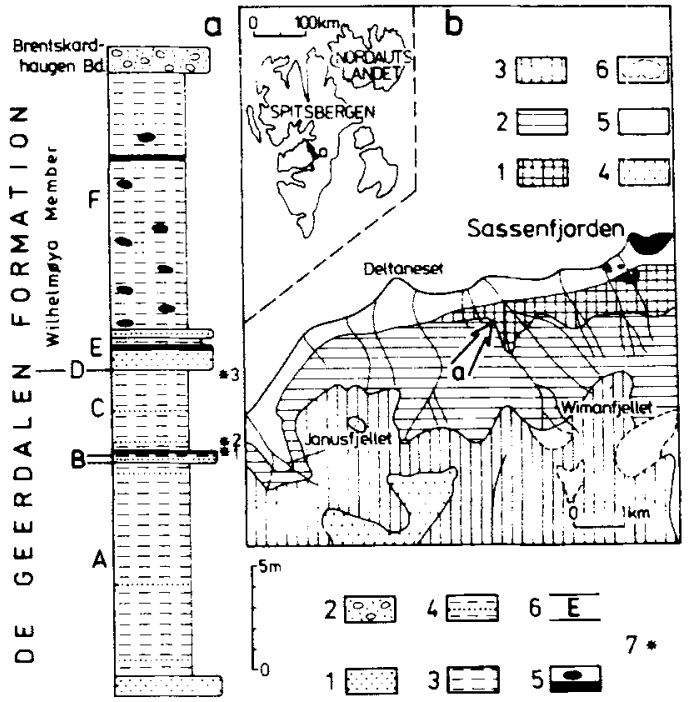

Fig. 1. Studied section at Wimanfjellet and its location on Spitsbergen. Da. 1 sandstones, 2 conglomerates and conglomeratic sandstones. 3 shales and silty shales, 4 thin intercalations of fine-grained sandstones and mudstones within shales, 5 iron-stone layers and concretions. 6 designations of rock-units as used in present paper. 7 samples bearing pyroclastic material. $\square$ b. Geological map of the investigated area (after Major and Nagy 1972) and its position within Svalbard (inset). Arrow: the location of the section studied. 1 De Geerdalen Fm. (Upper Triassic-Lower Jurassic), 2 Janusfjellet Fm. (Jurassic-Lower Cretaceous). 3 Helvetiafjellet Fm.-Carolinefjellet Fm. (Cretaceous), 4 Firkanten Fm.-Sarkofagen Fm. (PalaeoceneEocene), 5 Quaternary superficial deposits, 6 glaciers.

\& Dypvik 1977). The oldest marine fossils have been collected from units B and C: some pelecypods of undoubtedly Late Triassic age, and planktonic foraminifer Schmidita hedbergelloides Fuchs, which may be considered indicative of the Uppermost Norian and Rhaetian (cf. Wierbowski et al. 1981). The palynological assemblage derived from units $D$ and $F$ (except for its uppermost part) is also indicative of the Rhaetian (Bjærke \& Dypvik 1977). However, in unit F pelecypods have also been found, including representatives of the genus Halobia, which is not known from deposits of a post-Norian age. These finds support the opinion of Korchinskaya (1980), who assigned the uppermost part of the Triassic sequence in the Sassenfjorden area to the Lower Norian. Taking into account all these data, it can be safely assumed that the sequence under discussion may correspond either to the Norian or to the Rhaetian. Near the top of unit F, following a significant break in sedimentation, there appear deposits of late Early Jurassic age (Bjærke \& Dypvik 1977).

\section{Petrographic characteristics of samples bearing pyroclastic material}

Material of volcanic origin has been found only in samples taken from unit $\mathrm{C}$. Two of them come from the lowermost part of the unit: sample 1 from the iron-stone layer about $0.1-0.3 \mathrm{~m}$ above the base of the unit, and sample 2 from the mudstones and fine-grained sandstones immediately above sample 1 . Sample 3 comes from silty shales representing the uppermost part of unit C. All samples were studied in thin section; the heavy minerals were separated from samples 2 and 3 .

\section{Sample 1. Sandy siderite}

The rock is composed of homogeneous micrite carbonate matrix (siderite) with scarce organic remains and fairly abundant fine-grained detrital material in the size-range $0.07-0.35 \mathrm{~mm}$. The detrital material includes quartz, $\mathrm{K}$-feldspar and plagioclase grains as well as mica flakes. Of particular interest are extremely sharp-edged quartz fragments of different shapes: triangles with very acute angles and concave sides, blades, strongly elongated needles and other forms with deep embayments (Fig. 3).

Quartz fragments shaped in this manner are typical pyroclastic constituents of volcanic ash. Biotite flakes (Fig. 4) chloritized to a considerable degree, and other chlorite flakes formed due to complete chloritization of biotite, should also be regarded as volcanogenic material. Additionally, small, light-greenish concentrations of clay minerals with low birefringence and low refractive indices may be observed. Most probably, these are fragments which were altered to aggregates or montmorillonite-celadonite.

Sample 2. Clay-mudstone intercalations (tuffites) in fine-grained sandstones

These intercalations occurring in fine-grained sandstones (quartz arenites) form minute 1 to $5 \mathrm{~mm}$ thick layers. The clay portions are made up largely of illite or a mixture of this mineral with other clay constituents. The brown colour is due to iron components. The mudstone portions are composed chiefly of fine detrital material embedded in a very low birefringent matrix. 


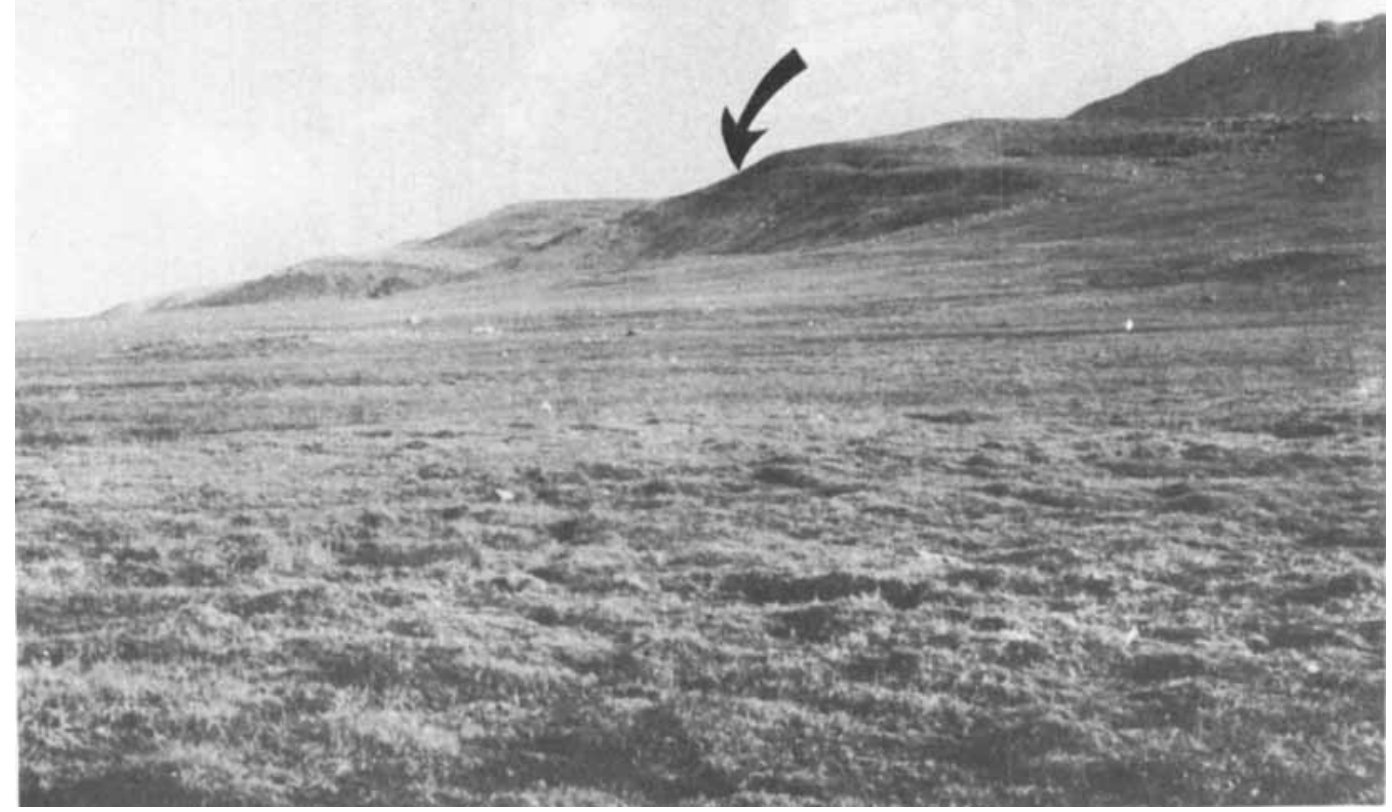

Fig. 2. Studied section north of Wimanfjellet, view towards the east; the position of strata bearing pyroclastic material is arrowed.

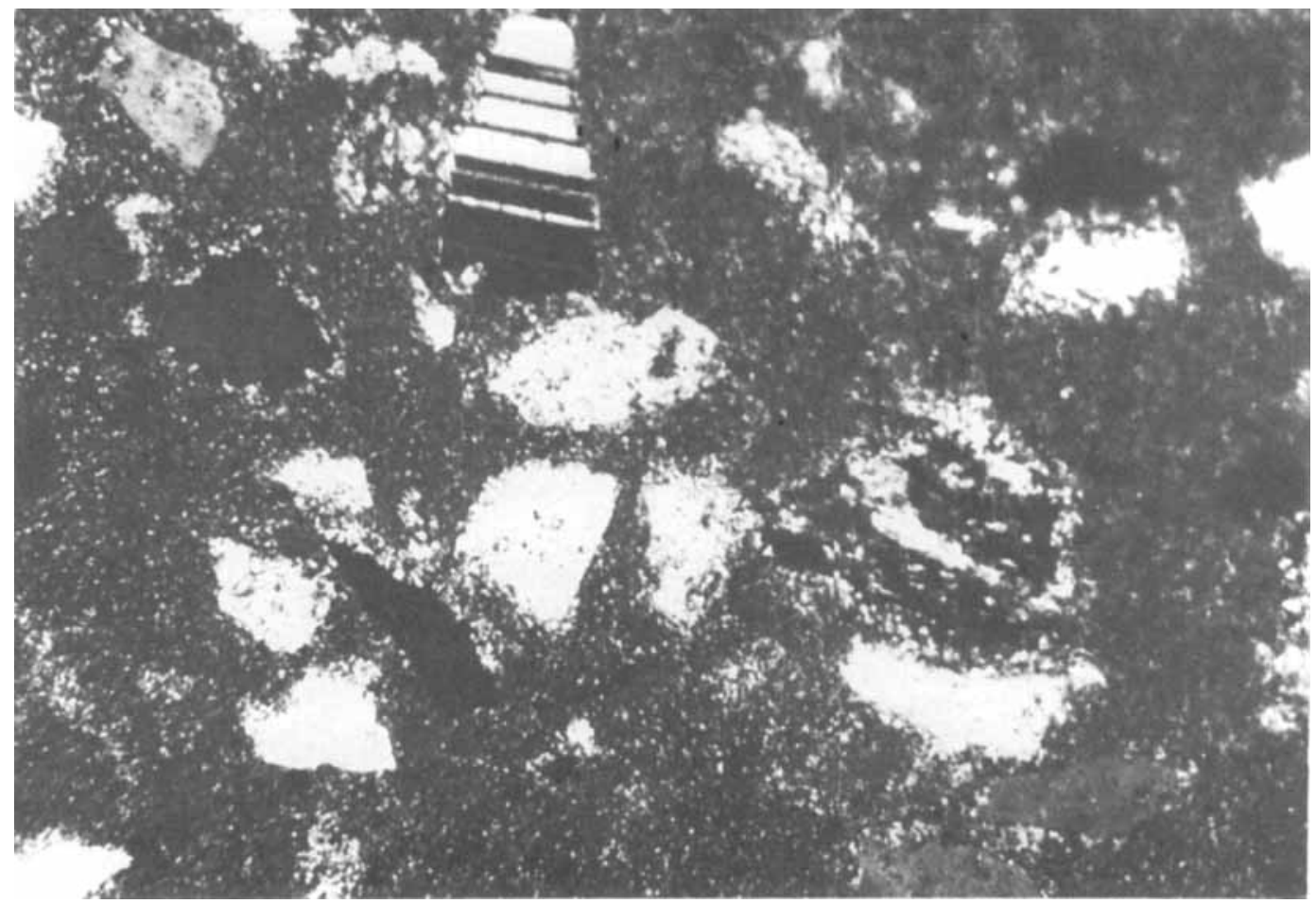

Fig. 3. Pyroclastic quartz in micrite sideritic matrix. Sample 1, Crossed nicols. 150x. 


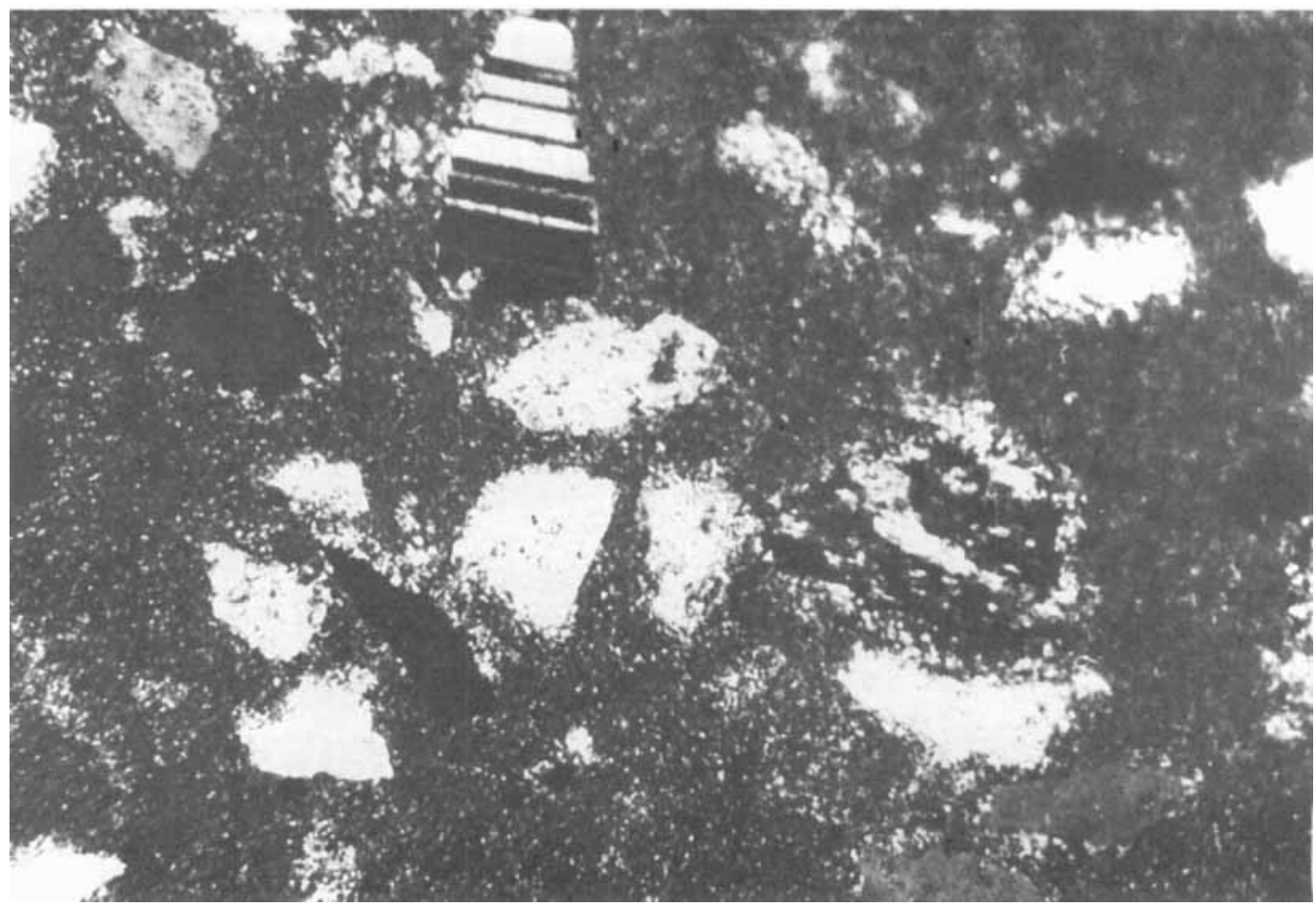

Fig. 4. Chloritized volcanogenic biotite flake (on the right) in sideritic matrix with fine-detrital material (quartz, feldspar). Sample 1. Crossed nicols. $150 \times$

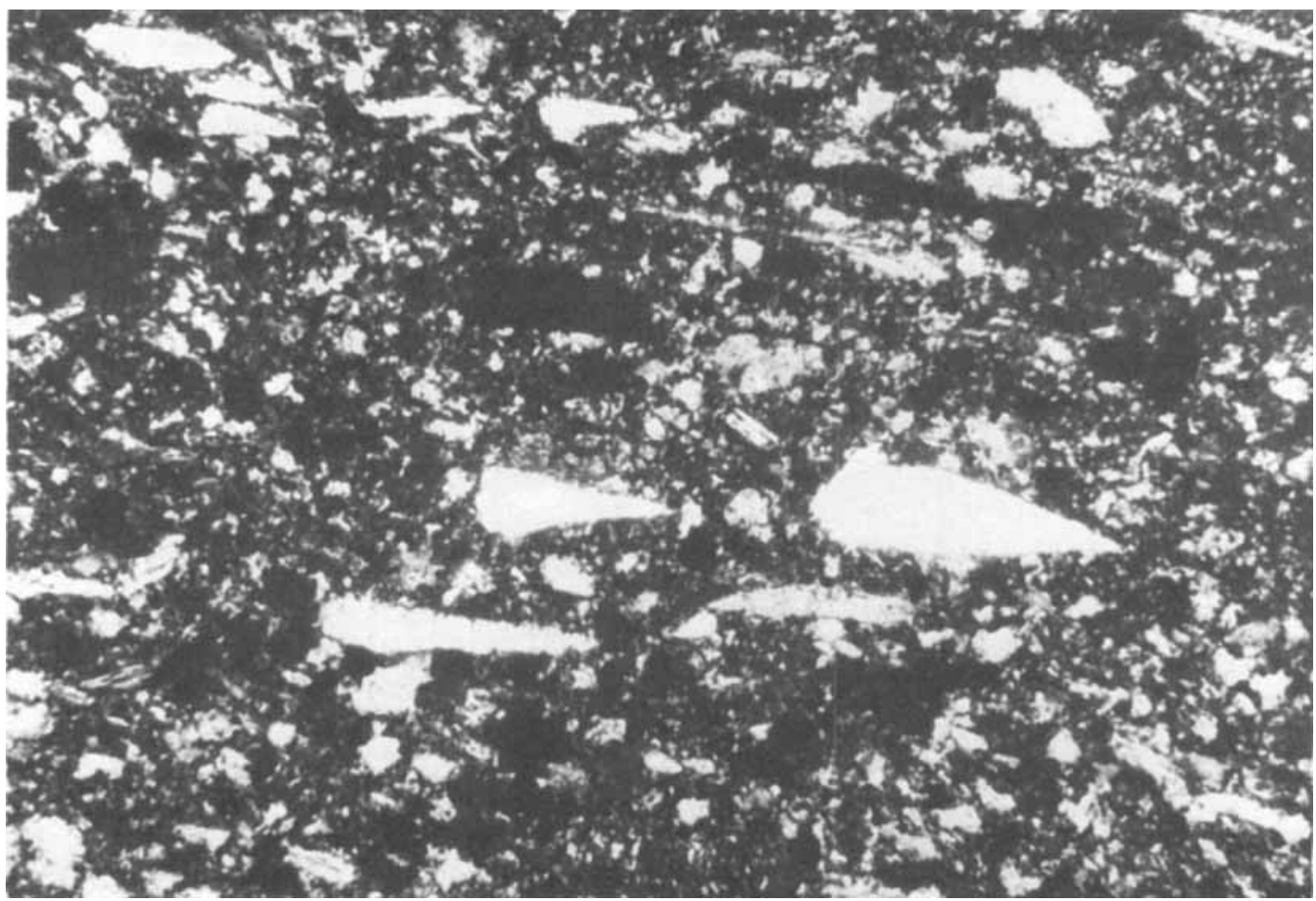

Fig. 5. Pyroclastic quartz in clay matrix with fine-detrital material. Sample 2. Crossed nicols. $150 \times$ 


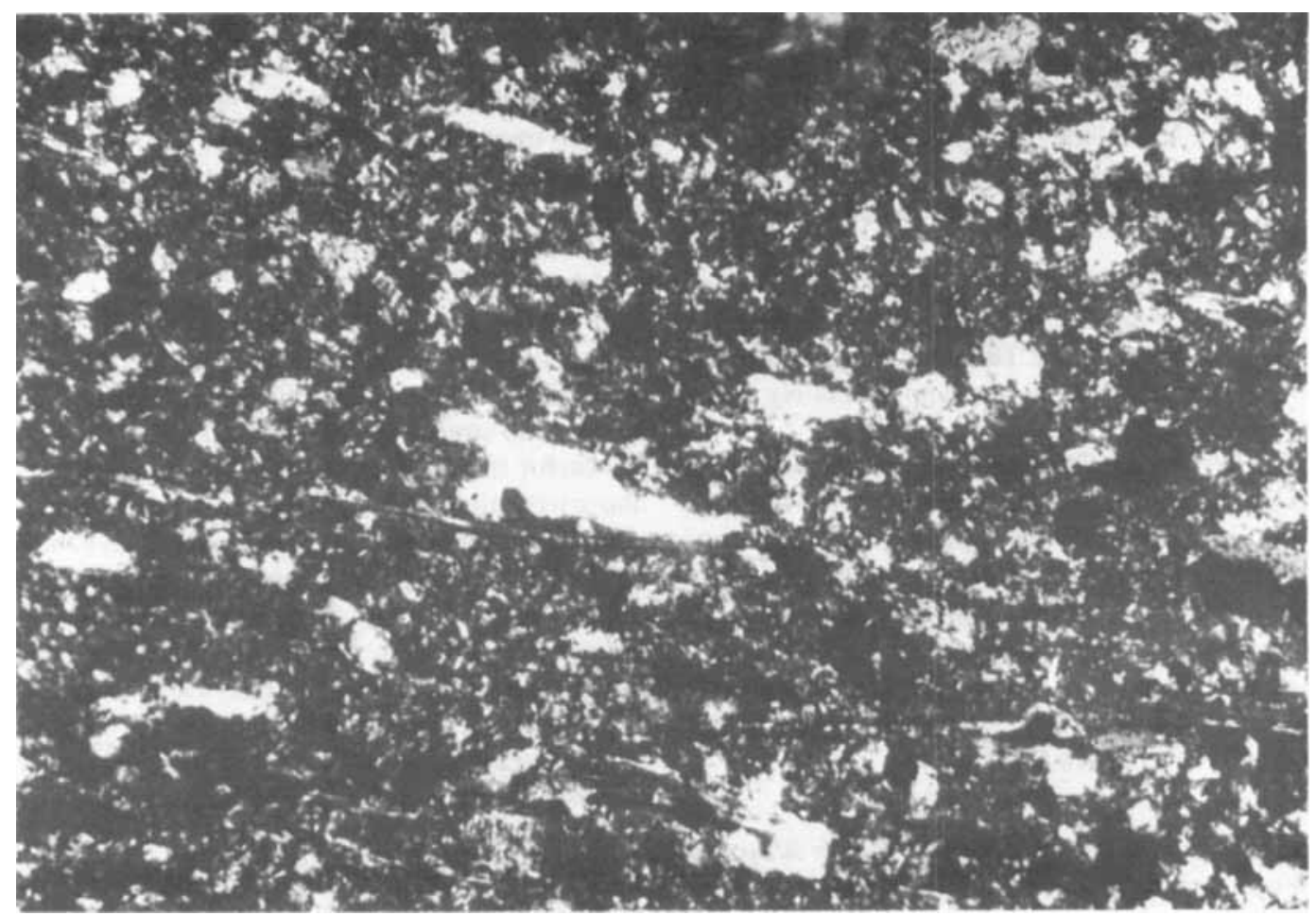

Fig. 6. Pyroclastic quartz with corrosional embayments. Sample 2. Crossed nicols. 150X.

The detrital material in the intercalations contains mostly quartz grains and mica flakes as well as subordinate feldspars - both K-feldspars (considerably decomposed) and plagioclase (albiteoligoclase). The accessory minerals identified in the heavy fraction are: zircon, apatite, staurolite, rutile, tourmaline, and garnet.

Attention is drawn to the very sharp-edged and concave-shaped quartz triangles, needles and blades (Fig. 5) typical of pyroclastic material. Deep embayments visible on the surface of some quartz grains are due to magmatic corrosion (Fig. 6.)

In addition to quartz, biotite occurring in the form of rectangular flakes $(010)$ is noted. Sometimes its brown pleochroic colours are very visible, but other individuals are affected by fairly intensive chloritization and thus show a pale green colour with a very low birefringence. Occasionally, chlorite flakes are observed exclusively, resembling the original biotite flakes only by their shape.

Zircon and apatite are idiomorphic. Zircon occurs in the form of small prisms terminated by well-developed pyramids, whereas the thin apatite prisms are terminated by pinacoids.

The size of the described minerals is fairly differentiated and ranges from 0.06 to $0.25 \mathrm{~mm}$ along the longer axis of the individual minerals. Biotite flakes and chlorite flakes are usually about 0.2 to $0.25 \mathrm{~mm}$ in size, while the idiomorphic zircon and apatite grains are from 0.1 to $0.15 \mathrm{~mm}$. The most distinct differentiation has been noted in quartz fragments which range from 0.06 to $0.25 \mathrm{~mm}$.

Quartz grains together with biotite, zircon, and the remaining constituents form fairly irregular thin streaks. Undoubtedly, these constituents are of volcanic origin. They show no evidence of mechanical reworking and their specific shapes indicate a direct derivation from a volcanic source. This material has not been redeposited.

The matrix in which the described mineral constituents are contained is very distinctive, too. It shows features typical of ash material, probably composed originally of volcanic glass. It is of very low birefringence, and sometimes even isotropic, locally completely devitrified. Sometimes the 
refractive indices of the clay matrix are lower than those of Canada balsam. The matrix is built of a clay mixture of illite-chlorite-kaolinite and of cryptocrystalline silica and possibly also of montmorillonite which is responsible for the lower refractive indices sometimes observed in the matrix.

The longer axes of the volcanic material are sub-parallel to the thin streaks in which the material accumulates. The intercalations containing volcanic material are approximately $5 \mathrm{~mm}$ thick.

Those parts of the mudstone rocks which are made up of detrital material (quartz, muscovite, and sporadic feldspar grains) are cemented together with clay material containing cryptocrystalline silica admixtures. In parts where the amount of matrix is less than $15 \%$, the rock acquires features of a fine-grained quartz arenite with a siliceous cement. No pyrogenic admixtures have been noted in these parts.

\section{Sample 3. Clay-silty shales with quartz siltstones intercalations}

The shales are made up chiefly of clay-micasiliceous matrix with very fine detrital material composed largely of quartz and mica. The quartz-mica dust is dispersed randomly in the matrix but sometimes form fairly distinct concentrations. Within this material. scarce, extremely sharp-edged quartz grains occur, the shapes of which resemble the pyroclastic material described from layer 2 .

\section{Conclusions}

Pyroclastic material is present in some thin layers from the shale and mudstone-sandstone sequence of the De Geerdalen Formation, immediately below the Wilhelmøya Member, in the Sassenfjorden area (Fig. 1). The material consists of quartz, biotite. zircon, apatite, and possibly also partly of clay minerals which may have developed through the alteration of volcanic glass. Based on the abundance of pyroclastic quartz grains. it can be stated that the material represents a volcanic ash with a rhyolitic composition.

The source of the material is not known, as there is no evidence or occurrence of volcanic rocks of Late Triassic age on Spitsbergen, and the neighbouring areas. Studies on recent and ancient volcanism suggest that pyroclastic material varying in grain-size from $0.06 \mathrm{~mm}$ to $0.25 \mathrm{~mm}$ (as stated in the area of Sassenfjorden) can be transported by wind currents from a distance of several dozen to several hundred kilometres from the site of eruption (cf. Hagman \& Spjeldnæs 1955; Hofmann 1958; Luchyckij 1971; Chlebowski 1978).

It should also be pointed out that the occurrence of intercalations containing pyroclastic material within the De Geerdalen Formation may have some stratigraphical significance, as it may be useful in resolving certain problems such as the correlation of the Wilhelmøya unit with its probable equivalents in other parts of Svalbard (cf. Worsley 1973). However, the studied sequence of the De Geerdalen Formation is actually the only one where the presence of Late Triassic pyroclastic material has been shown (cf. also Bjarke \& Dypvik 1977: 135, who mentioned 'rock fragments - volcanics' from the Upper Triassic deposits of the Sassenfjorden area). The scattered volcanic material in some Upper Triassic rocks of eastern Svalbard is interpreted (Flood et al. 1971) as derived from the weathering of a pre-existing volcanic mass (quartz-porphyry) of the Hecla-Hoek succession of Nordaustlandet.

Acknowledgements. - The paper resulted from field work carried out by a palaeontological group of the Polish Spitsbergen Expedition during the summer of 1979. The expedition was organized and sponsored by the Institute of Geophysics. Polish Academy of Science.

\section{References}

Bjerke. T. \& Dypvik, H. 1977: Sedimentological and palynological studies of Upper Triassic-Lower Jurassic sediments in Sassenfjorden. Spitsbergen. Nor. Polarinst. Årb. 1976, $131-150$

Chlebouski, R. 1978: Petrographic study of Early Paleozoic tuffogenic rocks from the Holy Cross Mts. Arch. Miner. 34 (1) 69-134. Warszawa

Flood. B.. Nagy, J. \& Winsnes T. S. 1971: The Triassic succession of Barentsøya, Edgeøya, and Hopen (Svalbard). Nor. Polarinst. Medd. No. 100, 1-24.

Hagemann, F. \& Spjeldnæs, N. 1955: The Middle Ordovician of the Oslo region, Norway: 6. Notes on bentonites (Kbentonites) from the Oslo-Asker district. Nor. Geol. Tidsskr. 53. $29-52$.

Hofmann, F. 1958: Das Bentonitvorkommen von Le Locke (Kanton Neuenburg). Ecl. Geol. Helvetiae. 51/1. 65-74.

Korchinskaya, M. V. 1980: Rannenorijskaya fauna arkipelaga Svalbarda (Early Norian fauna of Svalbard). In: Semevskij. D. V. (ed). Geologija osadochnovo chekhla arkhipelaga Svalbard (Geology of sedimentary cover of Sualbard) Niiga. 30-43. Leningrad. 
Lutchytskij, I. 1971: Osnovy paleovulkanologij. 1, 1-479. Moscow.

Wierzbowski, A., Kulicki, C. \& Pugaczewska, H. 1981: Fauna and stratigraphy of the Uppermost Triassic and the Toarcian and Aalenian deposits in the Sassenfjorden, Spitsbergen.
Acta Pal. Polonica. 26/3. Warszawa.

Worsley, D. 1973: The Wilhelmøya Formation - a new lithostratigraphical unit from the Mesozoic of eastern Svalbard. Nor. Polarinst. Arb. 1971, 7-15. 
